Article

\title{
Reduction of Environmental Impacts Due to Using Permeable Pavements to Harvest Stormwater
}

\author{
Lucas Niehuns Antunes ${ }^{1, *(\mathbb{D})}$, Calum Sydney ${ }^{2}$, Enedir Ghisi ${ }^{1}\left(\mathbb{D}\right.$, Vernon R. Phoenix $^{2}$, \\ Liseane Padilha Thives ${ }^{1}$, Christopher White ${ }^{2}$ and Emmanuelle Stefânia Holdefer Garcia ${ }^{1}$ \\ 1 Department of Civil Engineering, Federal University of Santa Catarina, Florianópolis 88040-900, Brazil; \\ enedir.ghisi@ufsc.br (E.G.); liseanethives@gmail.com (L.P.T.); emmanuelle.holdefer@gmail.com (E.S.H.G.) \\ 2 Department of Civil and Environmental Engineering, University of Strathclyde, Glasgow G1 1XQ, UK; \\ calumsydney@icloud.com (C.S.); vernon.phoenix@strath.ac.uk (V.R.P.); chris.white@strath.ac.uk (C.W.) \\ * Correspondence: lucas_niehuns@hotmail.com; Tel.: +55-48-3721-2115; Fax: +55-48-3721-5191
}

Received: 16 September 2020; Accepted: 9 October 2020; Published: 13 October 2020

\begin{abstract}
While rainwater harvesting can provide additional water resources, this approach is largely undertaken using water from roofs. More recently, the potential for using stormwater harvested from permeable pavements was recognised as a potential additional water resource. The objective of this study was to estimate the reduction of environmental impacts caused by traditional drainage systems and centralised water utilities if permeable pavement systems were used to harvest stormwater for nonpotable purposes in buildings. The lifecycle environmental impacts and costs associated with the proposed pavements and hydraulic systems were assessed. The city of Glasgow was chosen as a case study. We used the Netuno computer programme to estimate the potential for potable water savings considering the use of stormwater for nonpotable purposes and the SimaPro software to perform a lifecycle assessment (LCA). With the implementation of permeable pavements and stormwater utilisation, great reductions in lifecycle emissions (i.e., $\mathrm{CO}_{2^{-}}, \mathrm{SO}_{2^{-}}$, and $\mathrm{PM}_{2.5}$-equivalent emissions) were observed. The proposed system also proved to be economically feasible, i.e., a payback period equal to 16.9 years. The results show the economic and environmental feasibility of permeable pavements when used on a large scale, proving to be an important strategy to reduce water and environmental stresses caused by centralised water utilities and traditional drainage systems.
\end{abstract}

Keywords: stormwater; permeable pavement; life cycle assessment; environmental impacts; drainage systems; water supply

\section{Introduction}

Rapid urbanisation has led to a considerable increase in impermeable surfaces, such as roads and roofs, significantly changing the natural hydrological cycle in urban centres [1]. Traditional drainage systems, which carry stormwater runoff quickly to a stream by piped systems, cause increases in runoff volume, peak flow, and pollutants taken to rivers [2]. Moreover, in cities with combined sewer systems, water from impermeable surfaces is combined with black water and greywater (water from toilets, washing machines, etc.) and sent to wastewater treatment plants for processing. Consequently, during peak flow, combined sewer networks can be overwhelmed and flood, releasing harmful pollutants into the environment. Concomitantly with this situation, some problems arise with climate change. According to Stott [3], global warming may lead to an increase in short-term floods, as there is a strong correlation between peak rainfall intensity and high temperatures. An effective solution to improve drainage efficiency in urban centres is the large-scale use of sustainable urban drainage systems (SUDS). SUDS are a source control of stormwater runoff by using infiltration and storage in situ to reduce runoff discharge. Treating water locally and reducing the possibility of overloading stormwater 
distribution networks not only effectively minimises urban flooding risk, but also significantly decreases runoff pollutant discharge [4].

Permeable pavements are well-known examples of SUDS, with the function of infiltrating stormwater and thus reducing water flow to the public drainage system. Besides reducing the amount of stormwater runoff, permeable pavements have a wide range of benefits, such as the filtration of heavy metals, solids and hydrocarbons [5,6], retention of oils and greases $[7,8]$, decrease in traffic noise [9], decrease in heat island effect $[10,11]$, decrease in water spray, and improvement of road visibility [12].

Selbig et al. [13] evaluated the ability of permeable pavements to improve the quality of stormwater runoff, concluding that suspended solids were reduced by approximately $60 \%$, total phosphorus load was reduced up to $43 \%$, and metals were removed up to $49 \%$. Bean et al. [14] estimated that nutrient retention using permeable pavements was 3.4 and $0.4 \mathrm{~kg} / \mathrm{ha} / \mathrm{year}$ for total nitrogen and total phosphorus, respectively. Also, the concentrations of total Kjeldahl nitrogen, ammonia, total phosphorus, and zinc were significantly lower in the permeable pavement stormwater sample. Other studies also showed great results regarding stormwater quality collected from permeable pavements [15-17]. It is important to highlight that there are various types of permeable pavements with different permeable surfaces (such as porous asphalt, pervious concrete, and permeable interlocking concrete, among others), and a variety of layers and designs (total infiltration of stormwater, partial infiltration, or without infiltration). This diversity can influence the infiltration rate and stormwater quality, and is crucial in terms of lifecycle environmental and costs analyses [18,19].

Awareness of the prediction and prevention of environmental impacts related to drainage systems is increasing. Thus, interest in developing methods to better understand and deal with these impacts grows. One of the methods developed for this purpose is the lifecycle assessment (LCA) [20]. According to Liu et al. [21], there is still a lack of data supporting permeable pavement as an alternative to traditional impervious pavements and conventional drainage systems. It is also necessary to develop comprehensive assessment methods for decision-making between these various pavement alternatives. Turco et al. [22] studied the lifecycle environmental benefits of a permeable pavement, considering the potential removal efficiency of the metals. Bhatt et al. [23] concluded that approximately $50 \%$ of the environmental impacts of the permeable pavement lifecycle were linked to the raw material manufacturing process. Lu et al. [24] compared the environmental impacts of permeable pavements and conventional pavements and concluded that there was no significant advantage in reducing energy consumption and greenhouse gas emissions by implementing a porous asphalt pavement. However, many studies neglected some environmental benefits resulting from permeable pavements, considering only the materials needed for implementation and the energy consumed during the operation stage. It is also noteworthy that the studies do not consider the possible use of stormwater harvested by permeable pavements for nonpotable purposes, except for Vaz et al. [25]. Therefore, to better understand the interaction between the characteristics of the pavement and its environmental impacts, more practical case studies are needed [21].

It is notable that urban centres increasingly need decentralised drainage and water supply systems. However, the scarcity of research related to the use of stormwater harvested from permeable pavements is clear. Therefore, the objective of this study was to develop a method to estimate the reduction of environmental impacts caused by traditional drainage systems and centralised water utilities if permeable pavement systems were used to harvest stormwater for nonpotable purposes in buildings. Unlike other studies found in the literature, which present single roads or single parking-lot analyses, this study proposes the analysis in communities or even an entire city. The lifecycle environmental impacts and costs associated with the permeable pavements and hydraulic systems proposed were assessed. This method could be used for any region in the world, as it uses a series of daily rainfall and paved surface area data specific to each region. 


\section{Method}

The purpose of this method was to evaluate the potential for potable water savings in residential buildings in a large scale by designing roads and sidewalks as permeable systems capable of harvesting stormwater to be used for nonpotable purposes. Then, the lifecycle environmental impacts and costs associated with the proposed systems were compared with the current scenario (traditional drainage system and conventional water supply). The city of Glasgow was chosen as a case study to apply the method.

\subsection{Permeable Pavement and Quality of Stormwater}

The permeable pavement model adopted was composed of a draining asphalt concrete layer, a choker course and a reservoir layer. There was also a waterproof membrane to prevent stormwater from getting to the subgrade. Figure 1 shows the permeable pavement model and the stormwater harvesting system proposed. All the layers were sized according to the American Society of Civil Engineers (ASCE) [26]. The thickness of the reservoir layer was calculated according to Equation (1).

$$
h=t \times(R \times i-q) / n
$$

where $h$ is the thickness of the reservoir layer $(\mathrm{mm}), t$ is the duration of the rainfall $(\mathrm{h}), R$ is the ratio between the drainage area and the permeable pavement area, $i$ is the intensity of the design rainfall $(\mathrm{mm} / \mathrm{h}), q$ is the hydraulic conductivity of the subgrade $(\mathrm{mm} / \mathrm{h})$, and $n$ is the void volume of the reservoir layer (\%).

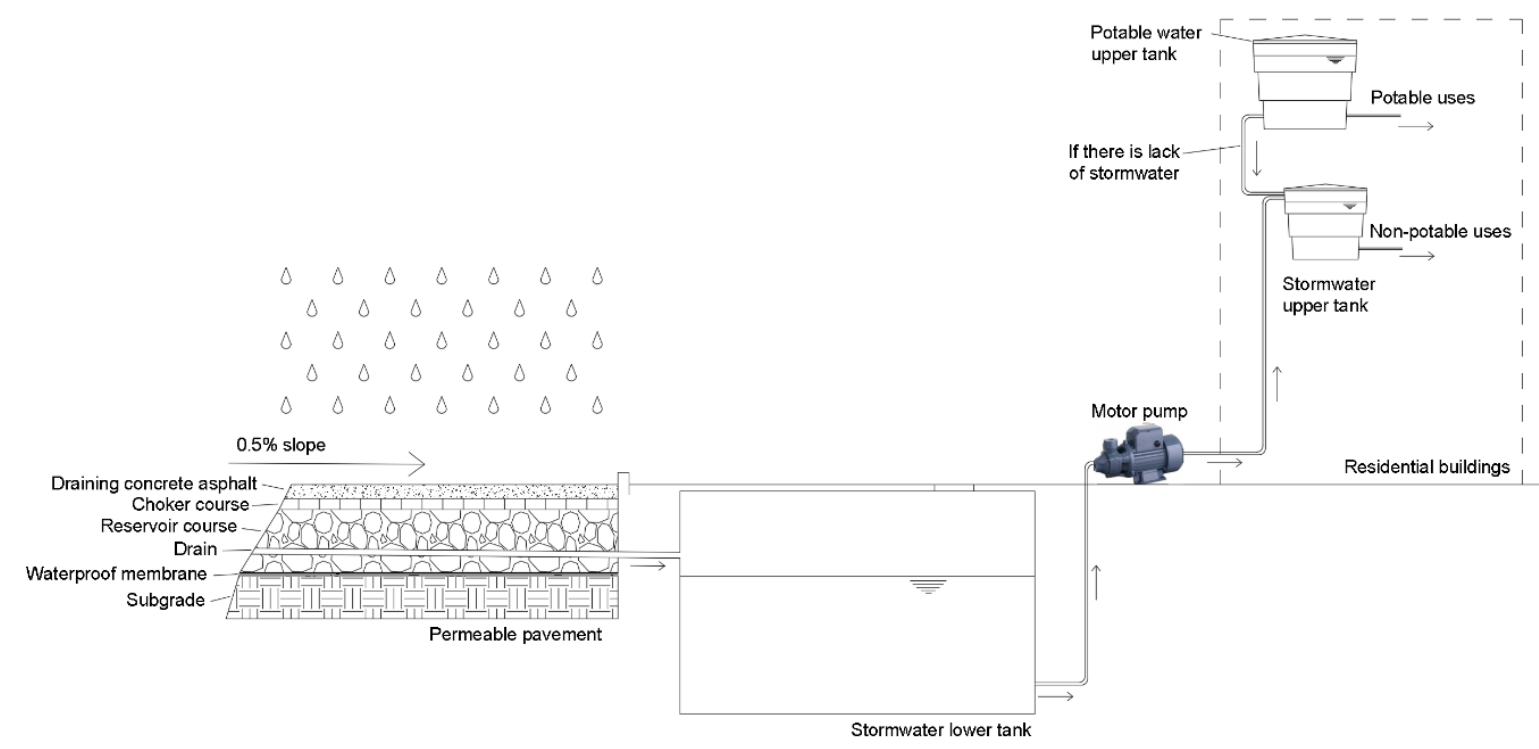

Figure 1. Permeable pavement model and stormwater harvesting system proposed.

Quality parameters that stormwater must meet to be used for nonpotable purposes (such as flushing toilets, cleaning outdoor areas, and garden watering) are indicated in Table S1 (in Supplementary Materials) [27]. We considered the use of chlorination as treatment. No first flush disposal device was used since the stormwater was filtered by the permeable pavement, which was able to remove sediments [28]. Additional treatment might be required in cases where chlorination is not sufficient to prepare the collected water for nonpotable uses (considering the parameters indicated in Table S1, in the Supplementary Materials). A minimum heavy metal removal and $\mathrm{pH}$ adjustment might be required. 


\subsection{Potential for Potable Water Savings}

Stormwater infiltrated in the permeable pavement was considered to be stored in one or more tanks and used for nonpotable purposes, such as flushing toilets and cleaning outdoor areas. The computer programme Netuno, version 4 [29], was used to assess the potential for potable water savings according to tank capacities and different community sizes. Input data for the computer simulations were daily rainfall, the surface area of paved roads, daily average total water demand, stormwater demand (as a percentage of total water demand), and infiltration rate of the permeable pavement.

The city of Glasgow was used as a case study. The Scottish Environment Protection Agency records rainfall data across the country using rain gauges [30], with the closest of these to the city-centre of Glasgow being at Dalmarnock Sewage Treatment Works (STW). Thus, daily rainfall over 15 years (16 September 2004 to 31 May 2019) from STW was used in the simulations. We ran simulations for different stormwater tank capacities, with the maximum tank capacity assessed being $5000 \mathrm{~m}^{3}$ and the interval between each capacity being $500 \mathrm{~m}^{3}$.

We used the Google Earth measuring tool to determine the width of the paved streets [31]. Some examples were taken for each type of road from different regions in Glasgow. The average width of each road type was then calculated and used to make an inference of the total road surface area. The length of the roads was measured using the latest published Scottish transport statistics [32]. The infiltration rate of the permeable pavement model is equal to $0.8(80 \%)$, as calculated by Hammes et al. [33] in a similar permeable pavement model. The $20 \%$ losses include aggregate absorption and evaporation. The pavement is cleaned twice a year, as recommended by Garcia et al. [34].

\subsection{Lifecycle Environmental Impacts}

The reduction of environmental impacts caused by traditional drainage systems and centralised water utilities compared to using permeable pavements to harvest stormwater was estimated based on the LCA guidelines, following the methodology proposed by ISO 14040 and 14044 standards [35,36]. The method can be applied to any region in the world, as it considers materials, daily rainfall time series, and paved surface area specific to each city.

The system function was considered to be the water supply in residential buildings of the city, therefore, the functional unit was the water supply in $\mathrm{m}^{3}$. Twenty years was considered to be the time horizon, as observed in other research works regarding permeable pavements and hydraulic systems $[37,38]$. The system boundary comprised the production of materials and components for the systems, including extraction of raw materials and processing, replacement of components over the lifespan of the systems, electricity consumption for system operation, and final disposal of components at the end of the system lifespan, considered to be a sanitary landfill, exclusively for construction debris. As this was a benchmark, all elementary processes identical in the proposed system and the current scenario were omitted, such as curbs and components necessary to the potable water system, among others. Also, the transportation of materials was not considered in this assessment, which could be considered a limitation of the study.

The inputs were inserted in the SimaPro software (PRé Consultants), version 9.0.0 using Ecoinvent 3.5 database [39]. At the impact assessment phase, fifteen midpoint impact categories were assessed. Table S2 (in the Supplementary Materials) shows the environmental impact categories defined in SimaPro, ReCiPe 2016 method, considering a hierarchical perspective and average global reference data [40]. We also grouped the midpoint categories into three endpoint categories, namely, human health, ecosystem quality, and resource scarcity.

\subsection{Lifecycle Cost Analysis}

To assess the economic feasibility of the permeable pavement systems, the costs due to implementation and maintenance, and the economic benefits of decreasing potable water consumption 
were obtained. The costs considered were initial costs, maintenance and labour costs, and benefits from potable water savings.

The initial costs were the sum of the labour costs and the costs of all materials used. The costs were obtained through research on the manufacturer's websites. The objective was to detail the components of the permeable pavement and stormwater system as much as possible. Labour costs were estimated through budget research on similar projects. For the permeable pavement, the costs of cleaning (such as twice-year sweeping) were estimated.

The economic benefits due to potable water savings arise from the reduction of costs in the treatment and distribution of water by the public water utility. The calculation of the monthly benefit was performed using Equation (2).

$$
E B_{i}=\left[C_{i} \times f_{i} \times\left(P_{\text {eco }} / 100\right)\right]-E_{\text {pumps }} \times F_{\text {elet }}
$$

where $E B_{i}$ is the economic benefit for month $i(£), C_{i}$ is the water consumption in month $i\left(\mathrm{~m}^{3}\right), f_{i}$ is the water tariff $\left(£ / \mathrm{m}^{3}\right), P_{\text {eco }}$ is the potential for potable water savings (\%), $E_{\text {pumps }}$ is the monthly energy consumption due to pumping stormwater in the new proposed system $(\mathrm{kWh})$, and $F_{\text {elet }}$ is the average fee paid for each $\mathrm{kWh}$ delivered in Glasgow $(£ / \mathrm{kWh})$.

The method used to evaluate the economic feasibility of the system was the discounted payback. We used the basic interest rate of Scotland's economy in July 2020, at $0.25 \%$ per year. The water and energy tariffs and the costs of cleaning the pavement were corrected according to the inflation rate of Scotland in July 2020 (1.19\% per year).

\section{Results and Discussion}

\subsection{Water Consumption and Water End-Uses by Residents in Glasgow}

The Government estimates that water consumption in the residential sector is $150 \mathrm{~L} /$ day per person [41]. The population of Glasgow was 611,748 in the last year [42], therefore, the total water consumption in the residential sector in Glasgow was estimated to be 91,762,200 L/day. Table 1 shows the end-uses of water within residential buildings [41], along with the average daily water consumption for each activity. The total percentage of nonpotable purposes was equal to $37 \%$ (flushing toilets and outdoor use), totalling 33,952,014 L/day for Glasgow's residential buildings.

Table 1. Water end-uses in the residential sector in Glasgow.

\begin{tabular}{cccc}
\hline Water End-Use & $\begin{array}{c}\text { Proportion of Total } \\
\text { Daily Use (\%) }\end{array}$ & $\begin{array}{c}\text { Amount of Water Used } \\
\text { (L/Day per Person) }\end{array}$ & $\begin{array}{c}\text { Amount of Water Used } \\
\text { in Glasgow (L/Day) }\end{array}$ \\
\hline Flushing toilets & 30 & 45.0 & $27,528,660$ \\
Taps (including baths) & 21 & 31.5 & $19,270,062$ \\
Washing machines & 13 & 19.5 & $11,929,086$ \\
Showers & 12 & 18.0 & $11,011,464$ \\
Drinking and other uses (e.g., cooking) & 9 & 13.5 & $8,258,598$ \\
Washing up & 8 & 12.0 & $7,340,976$ \\
Outdoor use (garden etc.) & 7 & 10.5 & $6,423,354$ \\
\hline Total & 100 & 150.0 & $91,762,200$ \\
\hline
\end{tabular}

Source: Scottish Government [41].

\subsection{Daily Rainfall Data}

The data were used to measure the daily rainfall at Dalmarnock STW between 16 September 2004 and 31 May 2019. Figure S1 (in the Supplementary data) shows the seasonal trend of precipitation throughout the last 15 years. Using the raw data obtained, the total annual rainfall for each full year was determined. These results are shown in Table S3 (in the Supplementary data). The average annual precipitation was $1032 \mathrm{~mm}$. 


\subsection{Total Surface Area of Paved Roads}

According to Transport Scotland [32], the total length of public roads in Glasgow is $1938 \mathrm{~km}$. The types of road in Glasgow were also detailed (Table S4, in the Supplementary data). Neither motorways nor their slip roads (Slip road is a short road on which vehicles join or leave a main road) were considered when calculating the total surface area of paved roads designed as permeable pavements because permeable surfaces do not have sufficient structural capacity to withstand such a high volume of traffic, including heavy goods vehicles, for a prolonged period [43]. Therefore, it would not be cost-effective to use permeable paving for these types of roads, where traditional impermeable surfaces are recommended for use. Given that motorways and slip roads were not considered, the total length of the roads and sidewalks to be designed as permeable systems was determined to be equal to $1832 \mathrm{~km}$. The width of roads and the total paved area are presented in Tables S5 and S6 (in the Supplementary data). The total surface area of paved roads was approximately equal to 2851 ha.

\subsection{Potential for Potable Water Savings}

Table 2 summarises the percentage of areas used in the simulations and also the paved roads area and the corresponding water consumption. The simulations explored different paved areas (percentage of the total in Glasgow). These simulations, therefore, essentially explored smaller and smaller sized communities $(100 \%$ means a population of 611,748 people and $0.1 \%$ represents a small residential community of 612 people within the city).

Table 2. Summary of paved roads area, community size, and water consumption.

\begin{tabular}{cccc}
\hline Paved Roads (\%) & Paved Roads $\mathbf{( m}^{2}$ ) & Water Consumption (L/Day) & Community Size \\
\hline 100 & $28,505,175$ & $91,762,200$ & 611,748 \\
50 & $14,252,588$ & $45,881,100$ & 305,874 \\
40 & $11,402,070$ & $36,704,880$ & 244,699 \\
30 & $8,551,553$ & $27,528,660$ & 183,524 \\
20 & $5,701,035$ & $18,352,440$ & 122,350 \\
10 & $2,850,518$ & $9,176,220$ & 61,175 \\
1 & 285,052 & 917,622 & 6117 \\
0.1 & 28,505 & 91,762 & 612 \\
\hline
\end{tabular}

Figure 2 shows the potential for potable water savings in residential buildings for different tank capacities and varying percentages of paved road surface areas. The larger the tank capacity and the smaller the community size considered, the greater the potential for potable water savings. We considered a tank capacity equal to $500 \mathrm{~m}^{3}$ for each $0.1 \%$ of the paved area (community size of 612 people), which was considered sufficient to supply a large percentage of the nonpotable water demand in this region $(34.5 \%)$, representing potable water savings equal to $31.7 \mathrm{~m}^{3} /$ day. Regarding stormwater supply, this tank capacity would completely meet water demand for nonpotable purposes for $92.1 \%$ of the days in a year, partially for $3.0 \%$, and not at all for $4.9 \%$ of the days.

\subsection{Permeable Pavement Hydraulic Design}

The average design rainfall intensity was considered to be $100 \mathrm{~mm} / \mathrm{h}$ [44]. The constant output flow was $118.75 \mathrm{~m}^{3} / \mathrm{h}$, corresponding to the discharge of $2850 \mathrm{~m}^{3}$ of stormwater in $24 \mathrm{~h}$. Stormwater volume was calculated by multiplying rainfall intensity $(100 \mathrm{~mm} / \mathrm{h})$ by the drainage area $\left(28,505 \mathrm{~m}^{2}\right.$, considering the optimal cluster size linked to a single water storage tank, as seen in Section 3.4). Thus, the specific output flow was found to be $4.17 \mathrm{~mm} / \mathrm{h}$. $\mathrm{R}$, the ratio between the contribution area and the permeable pavement area, was equal to 1.00 , since both the roads and sidewalks were permeable. We considered the void volume $\left(\mathrm{V}_{\mathrm{r}}\right)$ as 30\% [33]. Through Equation (1), the reservoir layer thickness was found to be $23.0 \mathrm{~cm}$. 


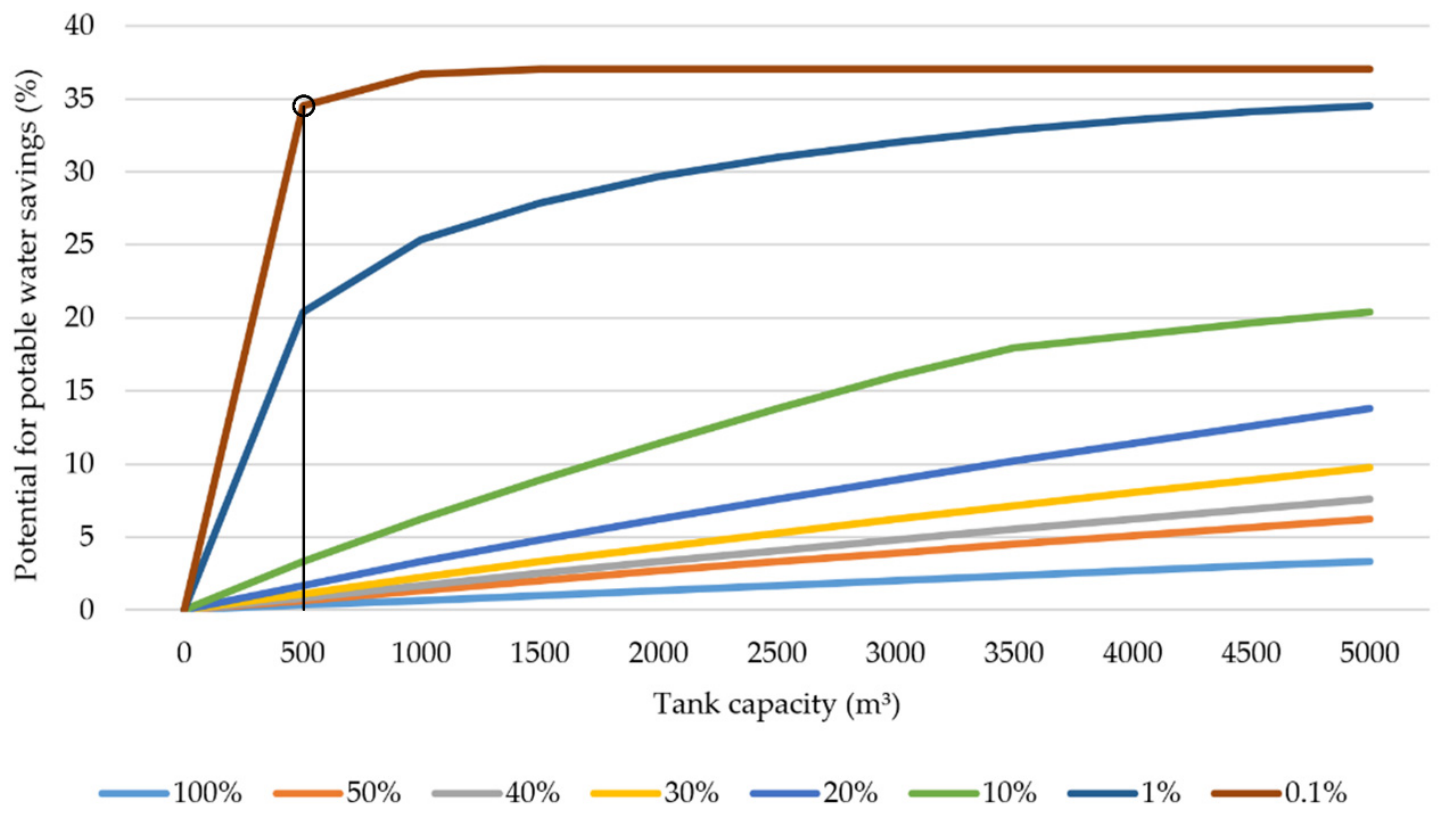

Figure 2. Potential for potable water savings for different paved road surface areas and tank capacities.

\subsection{Lifecycle Environmental Impacts}

We considered the optimal cluster size linked to a single water storage tank in order to compare the lifecycle environmental impacts between the proposed system (permeable pavement with stormwater harvesting) and the current scenario (traditional drainage system and conventional water supply). Thus, we considered a community size of 612 people, a paved area of $0.1 \%$ (which is equal to $28,505 \mathrm{~m}^{2}$ ), a stormwater tank with $500 \mathrm{~m}^{3}$ capacity, and a community water consumption of 91,702 L/day (as seen in Table 2).

The functional unit-water supply $\left(\right.$ in $^{3}$ ) for the community over the 20-year time horizon-was calculated based on the results shown in Section 3.1 and was equal to $669,864 \mathrm{~m}^{3}$. All input and output data of the proposed system and the current scenario were quantified and are presented in Tables S7 and S8 (in the Supplementary data). Chlorination for the water treatment and piping to handle overflow were considered in the quantification. The impacts related to cleaning the permeable pavement were estimated considering the use of a sweeper consuming approximately five litres of diesel per hour. We considered that each maintenance took six hours to be completed.

Figure 3 compares the environmental impacts (characterisation) through the midpoint categories selected for this study, as stated in Section 2.3. Most impacts caused by the current scenario (traditional drainage system and conventional water supply) were reduced due to the implementation of the permeable pavement system and stormwater utilisation.

Regarding the global warming category, the permeable pavement and stormwater utilisation scenario presented a reduction of $20.6 \%$ in $\mathrm{CO}_{2}$-equivalent emissions compared to the current scenario. The polystyrene production was the largest contributor of the permeable pavement scenario to this category, i.e., $9.8 \%$ of the total emissions. The high polystyrene production is due to the high number of pipes necessary to the stormwater system. The current scenario, in turn, showed the heat production process to be the most impacting for the global warming category, i.e., $27.0 \%$ of emissions. The high figure found for this process is mainly due to the production of hot mix asphalt (HMA), which is used as a conventional pavement surface course. 


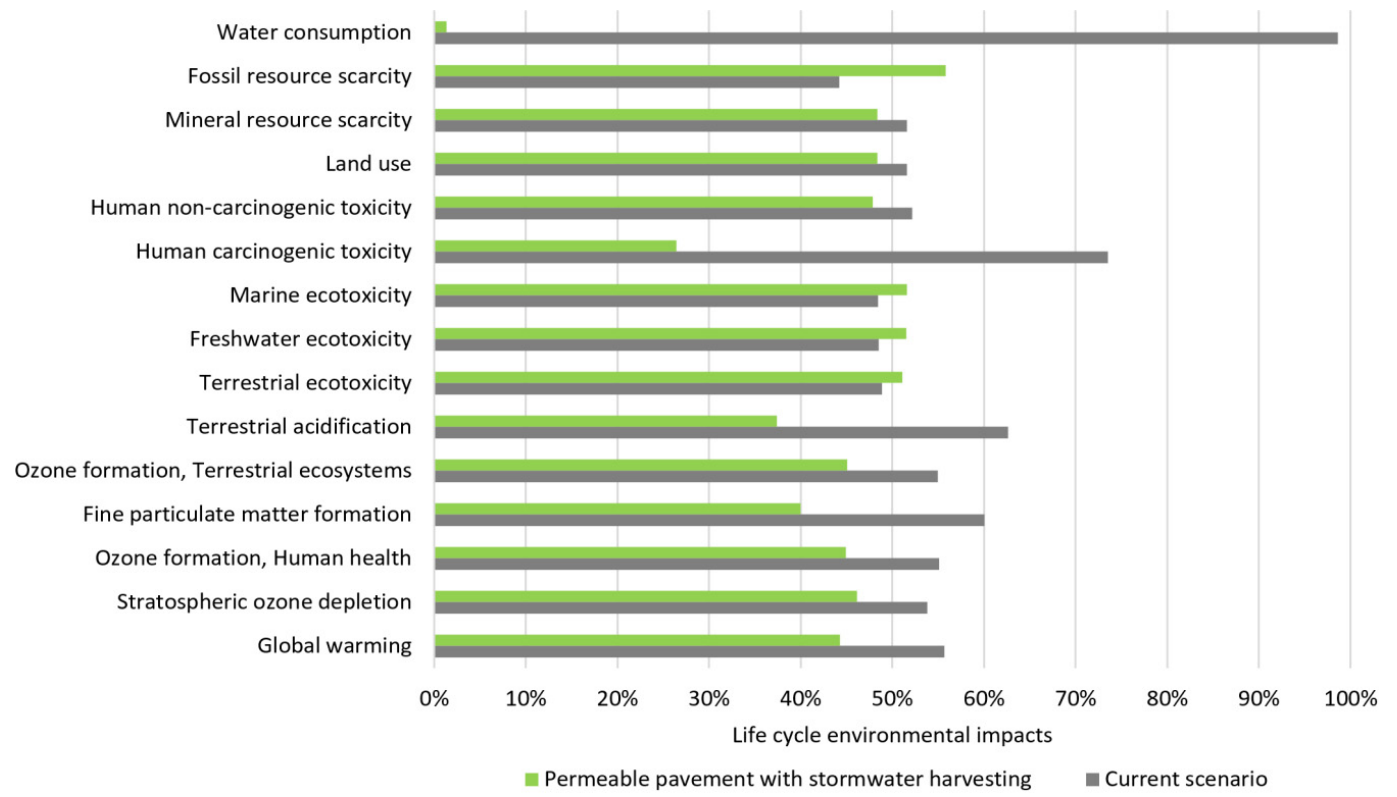

Figure 3. Comparison of environmental impacts through the ReCiPe midpoint method.

In the fine particulate matter formation category, the impact for the permeable pavement scenario was $33.3 \%$ lower compared to the current scenario. In the permeable pavement scenario, diesel processing was the process found to most contribute to the impacts in this category, i.e., $14.3 \%$ of equivalent $\mathrm{PM}_{2.5}$ emissions. In the current scenario, the heat production process again exhibited the most significant impact, i.e., $24.5 \%$ of equivalent $\mathrm{PM}_{2.5}$ emissions. The $33.3 \%$ higher result observed for the conventional scenario was mainly due to the use of hot mixture asphalt (HMA) in the conventional pavement surface, which demands high heat production and is responsible for increasing the levels of $\mathrm{PM}_{2.5}$ emissions [45]. The fine particulate matter formation category is related to air pollution and a negative impact on human health, ranging from respiratory symptoms to hospitalisations and deaths, represented by the $\mathrm{PM}_{2.5}$-equivalent unit, i.e., particulate matter with a diameter smaller than $2.5 \mu \mathrm{m}[40]$.

In the water consumption category, the impact for the scenario with permeable pavement and stormwater utilisation was $98.6 \%$ lower than the conventional scenario. This expressive result could be explained by the potable water production with conventional treatment in the current scenario, with this process having the greatest impact (50.9\%). Also, the process of distribution of this potable water by the water utility contributed to the greater damages. In this category, the water consumed for potable purposes (showering, washing machines, drinking and cooking, washing up, etc.) was omitted in the assessment, as explained in Section 2.4.

Regarding the human carcinogenic toxicity category, permeable pavements greatly reduced the impacts $(64.1 \%)$. The treatment of slag from unalloyed electric arc furnace steel was the process with the greatest impact in both scenarios. This process is related to the final disposal of slag in the landfill. In the human noncarcinogenic toxicity category, the treatment of sulfidic tailing was the most impacting in the permeable pavement scenario $(57.5 \%)$, while the treatment of spoil from hard coal mining was the most impacting in the conventional scenario (24.2\%).

In the fossil resource scarcity category, the permeable pavement showed a growth of $20.9 \%$ in the $\mathrm{kg}$ oil equivalent emissions due to the additional stormwater system proposed, with necessary pipes, connections, tanks, and valves to use the stormwater harvested. Such components use larger quantities of petroleum. Petroleum production was the most impacting process in both scenarios $(22.1 \%$ in the permeable pavement scenario and $19.7 \%$ in the conventional scenario). 
Treatment of waste natural gas burned in production flare was the process with the most significant impact on the terrestrial acidification category in the permeable pavement scenario. For the conventional scenario, heat production was the most impacting (31.1\%). The permeable pavement scenario achieved a $40.2 \%$ reduction in equivalent $\mathrm{SO}_{2}$ emissions for this category compared to the conventional scenario.

The other categories (mineral resources scarcity, land use, marine ecotoxicity, freshwater ecotoxicity, terrestrial ecotoxicity, ozone formation, and stratospheric ozone depletion) did not present relevant damages, as seen in the endpoint approach. Figure 4 shows the normalised environmental impacts for the two scenarios, showing midpoint impact categories with contributions to the endpoint approach.

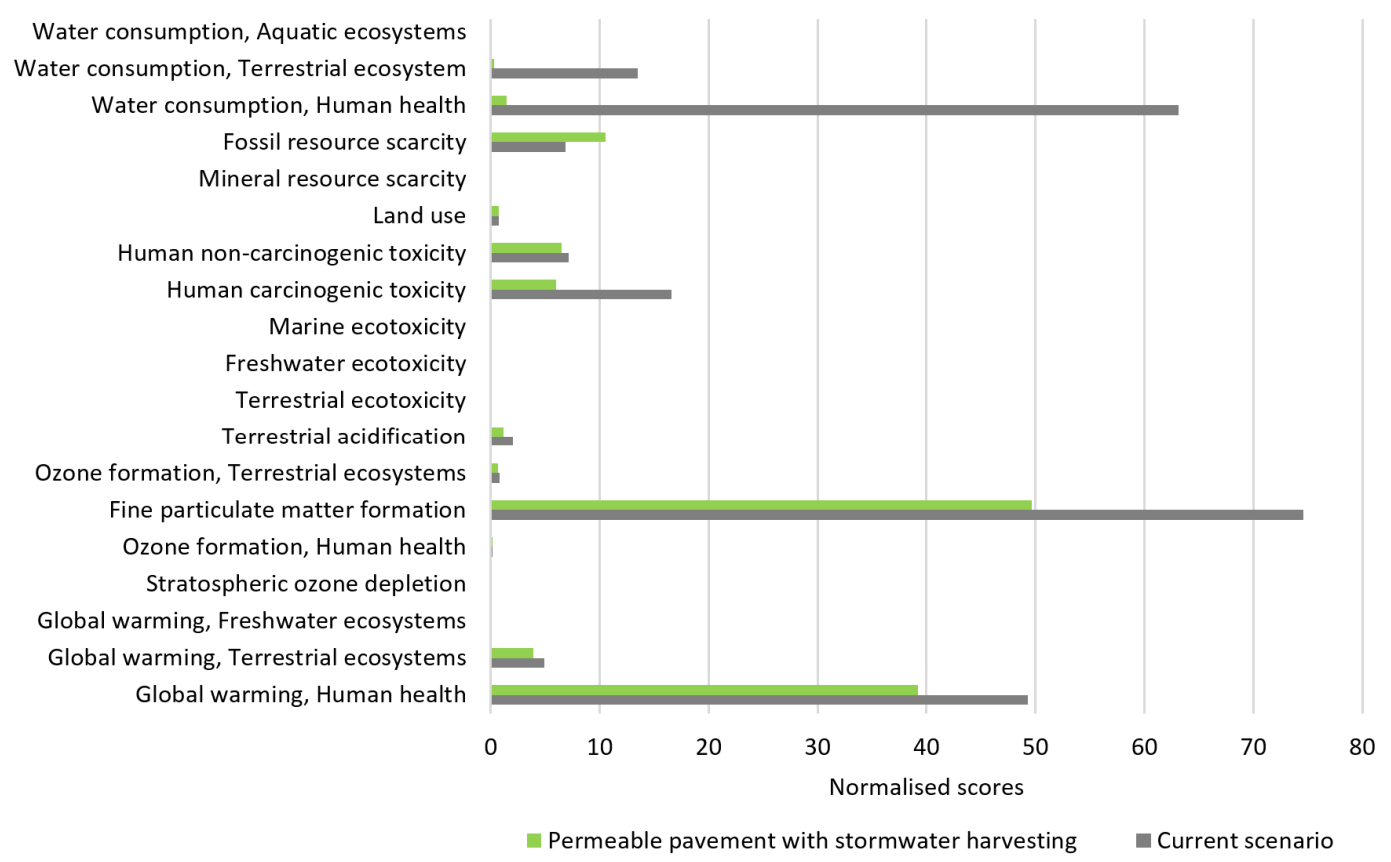

Figure 4. Comparison of scenarios using the ReCiPe endpoint method (normalised data).

Figure 5 shows the ReCiPe grouped endpoint categories (human health, ecosystems, and resources). Damage to human health was observed as the most impacting. The comparison of the two scenarios in a single score is shown in Figure 6, showing which scenario has the highest potential for environmental impact by totalling the weighted data for each impact category. An overall reduction of approximately $47 \%$ in environmental impact was obtained using the proposed system. Water consumption, fine particulate matter formation, and global warming (damage to human health) were the most impacting categories.

Although most studies found in the literature did not take into account the use of stormwater infiltrated in permeable pavements, several authors found a better environmental performance for the lifecycle of permeable pavements compared to traditional pavements. Liu et al. [21] showed better lifecycle performance for permeable asphalt pavement compared to dense-graded asphalt pavement in terms of energy consumption, global warming potential, acidification potential, smog formation potential, and human toxicity potential. Lu et al. [24], in turn, concluded that porous asphalt pavement did not show a significant advantage in reducing energy consumption and greenhouse gas emissions compared to the normal dense asphalt due to the heating required to produce asphalt. In the study of Lu et al. [24], the permeable feature of pavement was not considered, explaining the nondifference between the environmental impacts of the pavements. 


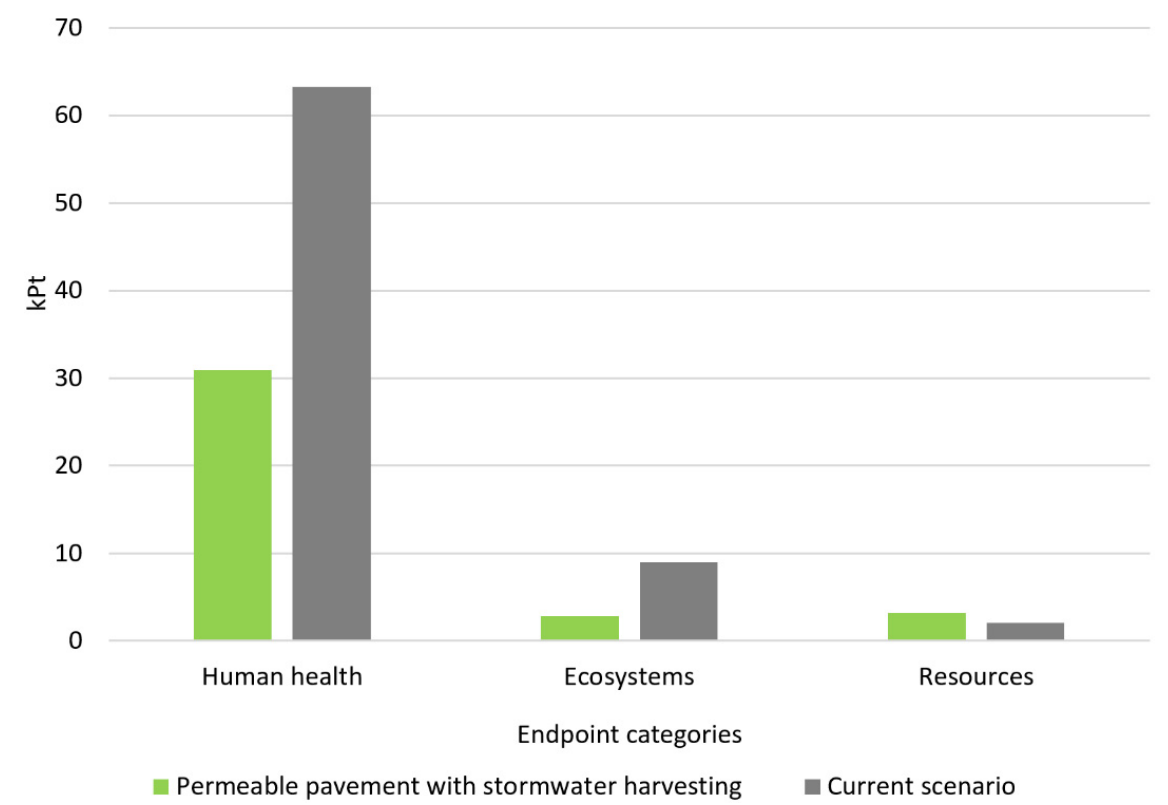

Figure 5. Comparison of scenarios through the endpoint categories (weighted data).

80,000

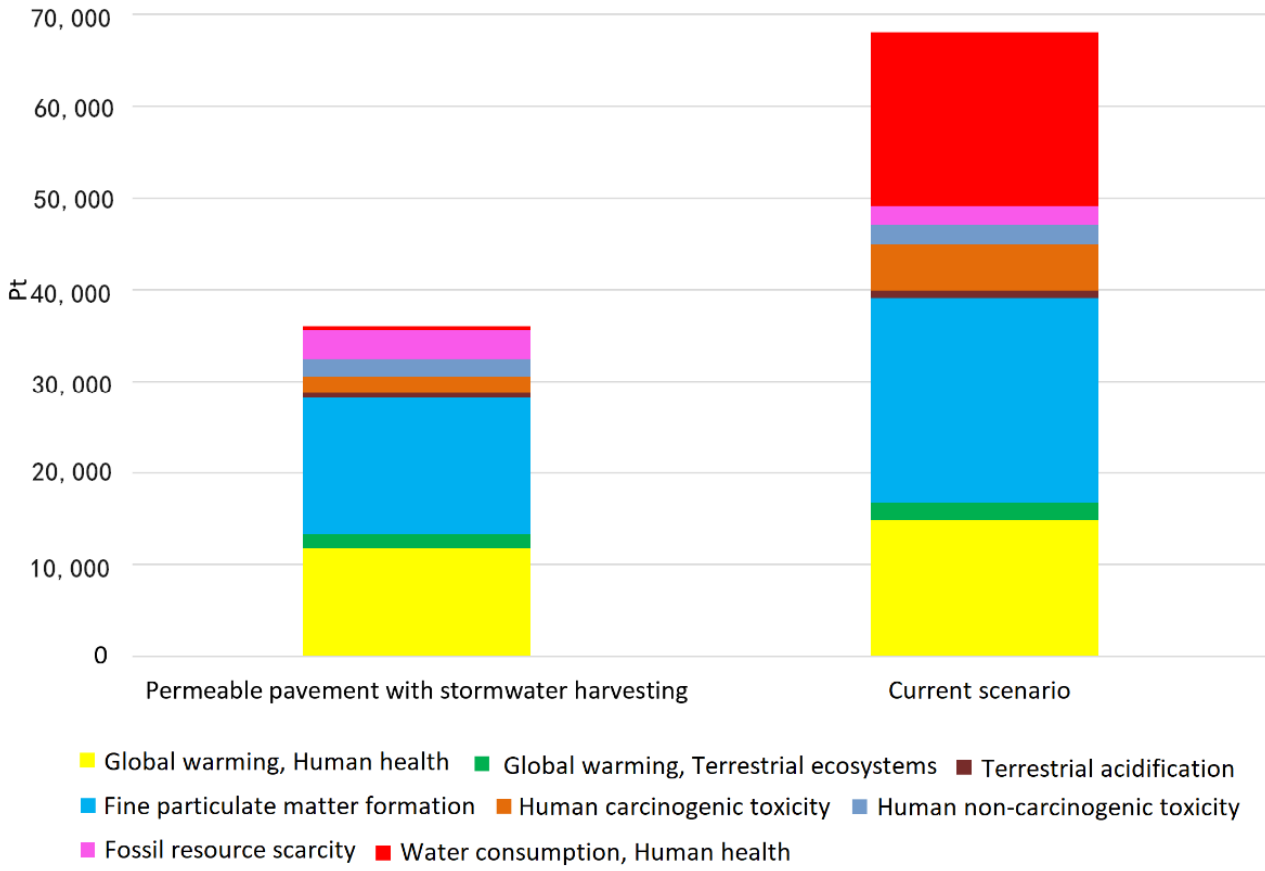

Figure 6. Comparison of scenarios using the ReCiPe endpoint method (single score).

\subsection{Lifecycle Cost Analysis}

Table 3 shows the initial costs for permeable pavement with a stormwater harvesting system. The total initial cost, including materials and labour, was equal to $£ 3,248,476.40$, representing $£ 113.96 / \mathrm{m}^{2}$. The structure of the permeable pavement was responsible for $72.9 \%$ of the total initial costs, while the drains and the components necessary for the stormwater system (pipes, connections, tanks, and valves) were responsible for $6.6 \%$ and $20.5 \%$, respectively. 
Table 3. Initial costs for the permeable pavement with a stormwater harvesting system.

\begin{tabular}{|c|c|c|c|c|}
\hline Components & Material & Quantity & Unit Cost $(£)$ & Total Cost $(£)$ \\
\hline Upper stormwater tanks & HDPE & $295 \times 500 \mathrm{~L}$ & 276.00 & $81,420.00$ \\
\hline \multirow{4}{*}{ Lower stormwater tank } & Concrete & $225 \mathrm{~m}^{3}$ & 150.00 & $33,750.00$ \\
\hline & Formwork wood & $390 \mathrm{~m}^{2}$ & 75.00 & $29,250.00$ \\
\hline & Steel bar & 34.87 ton & 4280.00 & $149,243.60$ \\
\hline & Geotextile & $425 \mathrm{~m}^{2}$ & 6.00 & 2550.00 \\
\hline Drain & Precast concrete & $2136 \mathrm{~m}$ & 100.00 & $213,600.00$ \\
\hline \multirow{3}{*}{ Asphalt coating } & Stone dust & $613 \mathrm{~m}^{3}$ & 165.60 & $101,512.80$ \\
\hline & Aggregates (4.8-9.5 mm) & $812 \mathrm{~m}^{3}$ & 165.60 & $134,467.20$ \\
\hline & Asphalt binder & $470 \mathrm{~m}^{3}$ & 1240.00 & $582,800.00$ \\
\hline Choker course & Aggregates $19 \mathrm{~mm}$ & $855 \mathrm{~m}^{3}$ & 165.60 & $141,588.00$ \\
\hline Reservoir course & Aggregates $37 \mathrm{~mm}$ & $7468 \mathrm{~m}^{3}$ & 165.60 & $1,236,700.80$ \\
\hline Waterproof membrane & Geotextile & $28,505 \mathrm{~m}^{2}$ & 6.00 & $171,030.00$ \\
\hline Pipes & PVC & $3835 \mathrm{~m}$ & 82.00 & $314,470.00$ \\
\hline Connections & PVC & $162 \mathrm{~kg}$ & 290.00 & $46,980.00$ \\
\hline Solenoid valve & PVC & 1 unit & 276.00 & 276.00 \\
\hline Overflow siphon & PE & 1 unit & 40.00 & 40.00 \\
\hline Floating set of suction & Silicon & 1 unit & 858.00 & 858.00 \\
\hline Floating chlorinator & PS & 1 unit & 770.00 & 770.00 \\
\hline Register & Brass & 1 unit & 1300.00 & 1300.00 \\
\hline Water pumps & Cast iron & 2 units & 2800.00 & 5600.00 \\
\hline Level electro buoy & HDPE & 1 unit & 270.00 & 270.00 \\
\hline & Total initial costs & & & $3,248,476.40$ \\
\hline
\end{tabular}

Note: HDPE stands for high-density polyethylene; PVC stands for polyvinyl chloride; PE stands for polyethylene; PS stands for polystyrene.

The electricity consumption to pump stormwater was calculated by multiplying the power of the water pumps $(\mathrm{kW})$ by the daily time of usage (four hours), resulting in $8.83 \mathrm{kWh} /$ day. We considered the use of a $3 \mathrm{HP}$ water pump. The pumping costs were calculated by multiplying the total amount of energy consumed during the lifecycle of the system by the average rate that Glasgow residents pay to their energy utilities. The tariff used was $£ 0.17681$ per $\mathrm{kWh}$ [46]. The annual costs of cleaning the pavement twice-yearly were $£ 600.00$. The energy tariff and the costs of cleaning the pavement were corrected through the lifecycle analysis, according to Section 2.4.

The economic benefit of the decrease in potable water consumption in the buildings was then assessed using Equation (2). The water tariff considered was equal to $£ 2.422$ [47]. The average economic benefit calculated for the first year was $£ 28,023.75$. The water tariff was also corrected using the lifecycle analysis, according to Section 2.4.

Table 4 shows the initial costs for a conventional (impermeable) pavement with a traditional drainage system. The total initial cost, including materials and labour, was equal to $£ 2,766,076.82$, representing $£ 97.04 / \mathrm{m}^{2}$. Compared to the permeable pavement with a stormwater harvesting system, the initial cost of the conventional system was $14.9 \%$ cheaper. The structure of the pavement was responsible for $84.6 \%$ of the total initial cost, while the drainage components were responsible for $15.4 \%$ of the cost.

Considering the economic benefit of the decrease in potable water consumption (discounting the costs to pump stormwater and maintain the pavement), the discounted payback period of the proposed system would be 16.9 years. Therefore, the system can be considered economically feasible since its lifespan is equal to 20 years.

Studies that consider the hydraulic system necessary for stormwater harvesting are unusual. In the study developed by Vaz et al. [25], the initial cost for the construction of a traditional pavement was $35.7 \%$ lower compared to the implementation of a permeable pavement (including the hydraulic 
system). However, unlike our study, the drainage system required for the traditional pavement was not considered by the authors. The discounted payback ranged from 7 to 15 years.

Table 4. Initial cost for a traditional (impermeable) pavement with a conventional drainage system.

\begin{tabular}{cccccc}
\hline System & Components & Material & Quantity & Unit Cost $(\mathfrak{E})$ & Total Cost $(\mathfrak{E})$ \\
\hline \multirow{3}{*}{ Pavement } & Asphalt coating & Hot Mix Asphalt & $1425 \mathrm{~m}^{3}$ & 648.42 & $923,998.50$ \\
& Base & Crushed stone & $4276 \mathrm{~m}^{3}$ & 165.60 & $708,105.60$ \\
& Sub-base & Stabilized soil & $4276 \mathrm{~m}^{3}$ & 165.50 & $707,678.00$ \\
\hline \multirow{5}{*}{ Drainage } & Concrete for gutters & Concrete & $22.9 \mathrm{~m}^{3}$ & 150.00 & 3435.00 \\
& Precast concrete & Concrete & $143 \mathrm{~m}^{3}$ & 150.00 & $21,450.00$ \\
& Formwork & Wood & $26 \mathrm{~m}^{2}$ & 75.00 & 1950.00 \\
& Sand for mortar & Sand & $4.40 \mathrm{~m}^{3}$ & 165.60 & 728.64 \\
& Cement for mortar & Cement & $946 \mathrm{~kg}^{2}$ & 2.18 & 2062.28 \\
& Brick $5 \times 10 \times 20 \mathrm{~cm}$ & Brick & $10,080 \mathrm{units}$ & 0.86 & 8668.80 \\
& Precast concrete pipes & Concrete & $3880 \mathrm{~m}$ & 100.00 & $388,000.00$ \\
\hline \multicolumn{2}{c}{ Total initial costs } \\
\hline
\end{tabular}

\section{Conclusions}

This research proposed a method to evaluate the potential for potable water savings that could be obtained by designing roads and sidewalks as permeable systems capable of harvesting stormwater to be used for nonpotable purposes in the residential sector. The lifecycle environmental impacts and costs associated with the permeable pavements and hydraulic systems proposed were assessed to determine the reduction of environmental impacts from the current traditional drainage system and centralised water utility. The research carried out throughout this investigation determined that the use of permeable pavement for collecting stormwater could lead to significant potable water savings in Glasgow, the city chosen as the case study to apply this method. In fact, according to the optimal results obtained during this investigation, the amount of stormwater that theoretically could be harvested would be close to the nonpotable water demand in the residential sector. While retrofitting roads and storage tanks to harvest water from across the entire city is likely to be unfeasible, this work highlights the significant potential for road and pavement water harvesting to be included in new constructions or retrofits, where appropriate.

As for the lifecycle environmental impacts-even with the additional stormwater harvesting system (which requires the installation of pipes, connections, motor pumps, tanks, and valves, among others)-the permeable pavement system reduced the environmental impacts compared to the current scenario (traditional drainage system and conventional water supply). The greatest reductions were obtained in categories of water consumption, fine particulate matter formation $\left(\mathrm{PM}_{2.5}\right.$-equivalent emissions), and global warming ( $\mathrm{CO}_{2}$-equivalent emissions). The processes with the best opportunities for environmental improvements were heat production and petroleum processing, related to the HMA used in the traditional pavement.

Considering the economic benefit of the decrease in potable water consumption, the system proposed herein proved to be economically feasible via cost analyses, i.e., a discounted payback period equal to 16.9 years compared to the traditional system. The results of this study confirm that the use of stormwater harvested from permeable pavements for nonpotable purposes on a large scale may be an important and feasible strategy to reduce water and environmental stresses caused by centralised water utilities and traditional drainage systems.

Supplementary Materials: The following are available online at http://www.mdpi.com/2073-4441/12/10/2840/s1, Figure S1: Daily rainfall at Dalmarnock STW between 16/09/2004 and 31/05/2019; Table S1: Parameters for water non-potable purposes uses (ANA, 2005); Table S2: Midpoint impact categories considered for the study; Table S3: Annual rainfall at Dalmarnock STW between 2005 and 2018; Table S4: Lengths of different types of roads in Glasgow; Table S5: Average width of different road categories in Glasgow; Table S6: Total paved area in Glasgow; Table S7: Quantities of the components used in the proposed system (permeable pavement and 
stormwater harvesting); Table S8: Quantities of the components used in the current scenario (traditional pavement and drainage).

Author Contributions: L.N.A. and C.S. wrote the first draft of the article; E.G., V.R.P., L.P.T., C.W., and E.S.H.G. wrote the final version and contributed ideas regarding the structure and content of the article. All authors have read and agreed to the published version of the manuscript.

Funding: This study was supported by a UK National Academies GCRF Networking grant. The first author is thankful for Coordenação de Aperfeiçoamento de Pessoal de Nível Superior (CAPES) for the scholarship during the development of this research.

Conflicts of Interest: The authors declare that there is no conflict of interest.

\section{References}

1. Tedoldi, D.; Chebbo, G.; Pierlot, D.; Kovacs, Y.; Gromaire, M. Impact of runoff infiltration on contaminant accumulation and transport in the soil/filter media of Sustainable Urban Drainage Systems: A literature review. Sci. Total Environ. 2016, 569, 904-926. [CrossRef] [PubMed]

2. Wang, S.; Wang, H. Extending the Rational Method for assessing and developing sustainable urban drainage systems. Water Res. 2017, 144, 112-125. [CrossRef] [PubMed]

3. Stott, P. How climate change affects extreme weather events. Science 2016, 353, 1517-1518. [CrossRef] [PubMed]

4. Scholz, M.; Grabowiecki, P. Review of porous pavement systems. Build. Environ. 2007, 42, 3830-3836. [CrossRef]

5. Pagotto, C.; Legret, M.; Le Cloirec, P. Comparison of the hydraulic behaviour and the quality of highway runoff water according to the type of pavement. Water Res. 2000, 34, 4446-4454. [CrossRef]

6. Brattebo, B.O.; Booth, D.B. Long-term stormwater quantity and quality performance of porous pavement systems. Water Res. 2003, 37, 4369-4376. [CrossRef]

7. Newman, A.P.; Aitken, D.; Antizar-Ladislao, B. Stormwater quality performance of a macro-permeable pavement car park installation equipped with channel drain based oil and silt retention devices. Water Res. 2013, 47, 7327-7336.

8. Nnadi, E.O.; Newman, A.P.; Coupe, S.J.; Mbanaso, F.U. Stormwater harvesting for irrigation purposes: An investigation of chemical quality of water recycled in permeable pavement system. J. Environ. Manag. 2015, 147, 246-256. [CrossRef]

9. Knabben, R.M.; Trichês, G.; Gerges, S.N.Y.; Vergara, E.F. Evaluation of sound absorption capacity of asphalt mixtures. Appl. Acoust. 2016, 114, 266-274.

10. Qin, Y. A review on the development of cool pavements to mitigate urban heat island effect. Renew. Sustain. Energy Rev. 2015, 52, 445-459. [CrossRef]

11. Khankhaje, E.; Rafieizonooz, M.; Salim, M.R.; Khan, R.; Mirza, J.; Siong, H.C.; Salmiati, S. Sustainable clean permeable concrete pavement production incorporating palm oil fuel ash as cement replacement. J. Clean. Prod. 2018, 172, 1476-1485. [CrossRef]

12. Kevern, J.T.; Schaefer, V.R.; Wang, K. Mixture Proportion Development and Performance Evaluation of Permeable Concrete for Overlay Applications. ACI Mater. J. 2011, 108, 439-448.

13. Selbig, W.R.; Buer, N.; Danz, M.E. Stormwater-quality performance of lined permeable pavement systems. J. Environ. Manag. 2019, 251, 109510. [CrossRef] [PubMed]

14. Bean, E.Z.; Hunt, W.F.; Bidelspach, D.A. Evaluation of Four Permeable Pavement Sites in Eastern North Carolina for Runoff Reduction and Water Quality Impacts. J. Irrig. Drain. Eng. 2007, 33, 583. [CrossRef]

15. Pilon, B.S.; Tyner, J.S.; Yoder, D.C.; Buchanan, J.R. The Effect of Permeable Concrete on Water Quality Parameters: A Case Study. Water 2019, 11, 263. [CrossRef]

16. Huang, J.; He, J.; Valeo, C.; Chu, A. Temporal evolution modeling of hydraulic and water quality performance of permeable pavements. J. Hydrol. 2016, 533, 15-27. [CrossRef]

17. Liu, Y.; Bralts, V.F.; Engel, B.A. Evaluating the effectiveness of management practices on hydrology and water quality at watershed scale with a rainfall-runoff model. Sci. Total. Environ. 2015, 511, 298-308. [CrossRef]

18. Gulotta, T.M.; Mistretta, M.; Praticò, F.G. A life cycle scenario analysis of different pavement technologies for urban roads. Sci. Total. Environ. 2019, 673, 585-593. [CrossRef] 
19. Zhang, Z.; Sha, A.; Liu, X.; Luan, B.; Gao, J.; Jiang, W.; Ma, F. State-of-the-art of porous asphalt pavement: Experience and considerations of mixture design. Constr. Build. Mater. 2020, 262, 119998.

20. Antunes, L.N.; Ghisi, E.; Thives, L.P. Permeable pavements life cycle assessment: A literature review. Water 2018, 10, 1575. [CrossRef]

21. Liu, J.; Li, H.; Wang, Y.; Zhang, H. Integrated life cycle assessment of permeable pavement: Model development and case study. Transp. Res. Part D Transp. Environ. 2020, 85, 102381. [CrossRef]

22. Turco, M.; Brunetti, G.; Palermo, S.A.; Capano, G.; Grossi, G.; Maiolo, M.; Piro, P. On the environmental benefits of a permeable pavement: Metals potential removal efficiency and Life Cycle Assessment. Urban Water J. 2020. [CrossRef]

23. Bhatt, A.; Bradford, A.; Abbassi, B.E. Cradle-to-grave life cycle assessment (LCA) of low-impact-development (LID) technologies in southern Ontario. J. Environ. Manag. 2019, 231, 98-109. [CrossRef] [PubMed]

24. Lu, G.; Wang, Y.; Li, H.; Wang, D.; Oeser, M. The environmental impact evaluation on the application of permeable pavement based on life cycle analysis. Int. J. Transp. Sci. Technol. 2019, 8, 351-357.

25. Vaz, I.C.M.; Ghisi, E.; Thives, L.P. Life cycle energy assessment and economic feasibility of stormwater harvested from permeable pavements. Water Res. 2020, 170, 115322.

26. American Society of Civil Engineers (ASCE). Permeable Pavements: Recommended Design Guidelines; American Society of Civil Engineers: Reston, VA, USA, 2013; ISBN 9780784478677.

27. Agência Nacional de Águas (ANA). Water Conservation and Reuse in Buildings; Editora Gráfica: São Paulo, Brazil, 2005. Available online: http://az545403.vo.msecnd.net/uploads/2014/08/conservacao-e-reuso-deaguas-2005.pdf (accessed on 20 April 2020).

28. Deletic, A. The first flush load of urban surface runoff. Water Res. 1998, 32, 2462-2470. [CrossRef]

29. Ghisi, E.; Cordova, M.M. Netuno 4. Programa Computacional; Federal University of Santa Catarina, Department of Civil Engineering: Florianópolis, Brazil, 2014. Available online: http://www.labeee.ufsc.br/ (accessed on 15 April 2020).

30. Scottish Environment Protection Agency. Rainfall Data for Scotland. Available online: https://apps.sepa.org. uk/rainfall (accessed on 6 June 2020).

31. Google Earth. Available online: https://www.google.co.uk/intl/en_uk/earth/ (accessed on 18 June 2020).

32. Transport Scotland. Scottish Transport Statistics N ${ }^{\circ} 372018$ Edition. Edinburgh, UK, 2019. Available online: https:/www.transport.gov.scot/media/44025/scottish-transport-statistics-no-37-2018edition.pdf (accessed on 18 July 2020).

33. Hammes, G.; Thives, L.P.; Ghisi, E. Application of stormwater collected from permeable asphalt pavements for non-potable uses in buildings. J. Environ. Manag. 2018, 222, 338-347. [CrossRef]

34. Garcia, S.H.E.; Thives, L.P.; Ghisi, E.; Antunes, L.N. Analysis of permeability reduction in drainage asphalt mixtures due to decrease in void volume. J. Clean. Prod. 2020, 248, 119292. [CrossRef]

35. ISO 14040-Environmental Management. Life Cycle Assessment, Principles and Framework, 2006. Available online: https://www.iso.org/obp/ui/\#iso:std:iso:14040:ed-2:v1:en (accessed on 14 July 2020).

36. ISO 14044-Environmental Management. Life Cycle Assessment, Requirements and Guidelines, 2006. Available online: https://www.iso.org/obp/ui/\#iso:std:iso:14044:ed-1:v1:en (accessed on 14 July 2020).

37. Antunes, L.N.; Ghisi, E.; Severis, R.M. Environmental assessment of a permeable pavement system used to harvest stormwater for non-potable water uses in a building. Sci. Total Environ. 2020, 746, 141087. [CrossRef]

38. Marinoski, A.K.; Ghisi, E. Environmental performance of hybrid rainwater-greywater systems in residential buildings. Resour. Conserv. Recycl. 2019, 144, 100-114. [CrossRef]

39. Wernet, G.; Bauer, C.; Steubing, B.; Reinhard, J.; Moreno-Ruiz, E.; Weidema, B. The ecoinvent database version 3 (part I): Overview and methodology. Int. J. Life Cycle Assess. 2016, 21, 1218-1230.

40. Huijbregts, M.A.J.; Steinmann, Z.J.N.; Elshout, P.M.F.; Stam, G.; Verones, F.; Vieira, M.D.M.; Zijp, M.; Hollander, A.; Zelm, R. ReCiPe2016: A harmonised life cycle impact assessment method at midpoint and endpoint level. Int. J. Life Cycle Assess. 2017, 22, 138-147.

41. Scottish Government. Building Standards Technical Handbook 2017: Domestic Buildings. Available online: https://www.gov.scot/publications/building-standards-2017-domestic/1-structure/10introduction/ (accessed on 25 April 2020).

42. UK Population. Glasgow Population, 2019. Available online: https://www.ukpopulation.org/glasgowpopulation/ (accessed on 14 June 2019). 
43. Antunes, L.N.; Thives, L.P.; Ghisi, E. Potential for potable water savings in buildings by using stormwater harvested from permeable pavements. Water 2016, 8, 110. [CrossRef]

44. Chan, S.C.; Kahana, R.; Kendon, E.J.; Fowler, H.J. Projected changes in extreme precipitation over Scotland and Northern England using a high-resolution regional climate model. Clim. Dyn. 2018, 51, 3559-3577. [CrossRef]

45. Kitto, A.M.; Pirbazari, M.; Badriyha, B.N.; Ravindran, V.; Tyner, R.; Synolakis, C.E. Emissions of Volatile and Semi-Volatile Organic Compounds and Particulate Matter from Hot Asphalts. Environ. Technol. 1997, 18, 121-138. [CrossRef]

46. Selectra. Best Value Scottish Power Tariffs in 2020. Available online: https://selectra.co.uk/energy/providers/ scottish-power/tariffs\#: \{\}:text=At\%20the \%20date\%20of\%20publication,rate $\% 3 \mathrm{~A} \% 2017.681 \mathrm{p} \% 20$ per $\%$ 20kWh (accessed on 20 July 2020).

47. Scottish Water. Metered Charges 2019-2020. Available online: https://www.scottishwater.co.uk/your-home/ your-charges/your-charges-2019-2020/metered-charges-2019-2020 (accessed on 20 July 2020).

(C) 2020 by the authors. Licensee MDPI, Basel, Switzerland. This article is an open access article distributed under the terms and conditions of the Creative Commons Attribution (CC BY) license (http://creativecommons.org/licenses/by/4.0/). 